\title{
江西省两种鸟类新记录一一白喉斑秧鸡和红颈瓣蹼楺 Slaty-legged Crake and Red-necked Phalarope: Two New Bird Records from Jiangxi Province, China
}

\author{
钟平华 ${ }^{1}$, 邵明勤 ${ }^{2, *}$, 戴年华 ${ }^{3}$, 曾凡伟 ${ }^{2}$ \\ ZHONG Ping-hua ${ }^{1}$, SHAO Ming-qin ${ }^{2}$, DAI Nian-hua ${ }^{3}$, ZENG Fan-wei ${ }^{2}$ \\ (1. 江西省遂川县鸟类环志站, 江西 吉安 $343900 ; 2$ 江西师范大学 生命科学学院, 江西 南昌, 330022; \\ 3. 江西省科学院 生物资源研究所, 江西南昌 330029) \\ (1. Bird Banding Station of Suichuan, Jiangxi, Ji'an 343900, China; 2. College of Life Science, Jiangxi Normal University, Nanchang, 330022, China; \\ 3. Biological Resources Institute, Jiangxi Academy of Sciences, Nanchang 330029, China)
}

关键词: 江西; 遂川; 白喉斑秧鸡; 红颈瓣蹼璚; 新记录

Key words: Jiangxi Province; Suichuan; Rallina eurizonoides; Phalaropus lobatus; New distribution records

中图分类号: Q959.7 文献标识码: A 文章编号：0254-5853-(2009)01-0016-02

2006 年 10 月 2 日和 2007 年 8 月 21 日笔者在 江西吉安市遂川鸟类环志站 $\left(25^{\circ} 28^{\prime}-26^{\circ} 20^{\prime} \mathrm{N}\right.$, $\left.113^{\circ} 56^{\prime}-114^{\circ} 13^{\prime} \mathrm{E}\right)$ 进行鸟类环志和野外鸟类观测 过程中, 记录到白喉斑秧鸡（Rallina eurizonoides） 和红颈瓣蹼敄 (Phalaropus lobatus), 经查阅文献后 确认为江西省新记录 (Zheng, 2005)。现报道如下:

\section{1 白喉斑秧鸡 Rallina eurizonoides}

2006 年 10 月 2 日笔者在遂川鸟类环志站的营 盘圩乡山地（海拔 $1700 \mathrm{~m}$ ) 开展夜间环志时捕获一 只白喉斑种鸡, 捕获环志后放飞, 环号为 F05-2280。

形态特征: 偏栗棕色秧鸡。头部和胸栗棕色, 喉部色浅偏白, 下胸以下具粗大的黑褐和白色相间 的横斑。初级飞羽和次级飞羽的内侧亦具黑褐和白 色相间的横斑。

量度: 体重 $101 \mathrm{~g}$, 全长 $259 \mathrm{~mm}$, 嘴峰 $24 \mathrm{~mm}$, 翅长 $136 \mathrm{~mm}$, 尾长 $66 \mathrm{~mm}$, 跗蹠 $44 \mathrm{~mm}$ 。

分布: 白喉斑秧鸡的分布范围还不甚清楚 (MacKinnon et al, 2000)。以往文献记录表明, 该 物种在广西、香港、台湾为留鸟, 在湖南和河南南 部为夏候鸟, 亦见于海南 (迷鸟) 和云南 (Zheng, 2005; Huang et al, 2006)。Gao et al（2000）在太湖 进行鸟类调查时也发现白喉斑秧鸡。江西过去无分
布记录, 遂川鸟类环志站夜间环志的白喉斑秧鸡为 江西省鸟类新记录。此次发现时间为鸟类迁徙季 节, 因此该物种在江西的居留状况还有待进一步观 察。

\section{2 红颈瓣蹼鹬 Phalaropus lobatus}

2007 年 8 月 21 日笔者在遂川沙子岭机场附近 的湿地发现红颈瓣蹼预岛 1 只, 该鸟在机场附近的湿 地停留两天。

形态特征：嘴细长而直, 上体灰色和白色, 下 体偏白。头顶及眼周黑色, 白色眉纹明显, 粗大的 黑色贯眼纹十分显著。眼后耳羽向下至颈前有橙黄 色纵纹。据形态特征推测该物种可能正处于换羽阶 段。

分布: 红颈瓣蹼敄分布广泛, 繁殖于全北界, 于世界各地的海上越冬。在国内除海南外均为旅 鸟。该物种在国内分布于东北全境、河北、北京、 辽宁、山东、青海、新疆、江苏、上海、福建、广 东、香港、海南和台湾(MacKinnon et al, 2000; Zheng, 2005)。Zhong et al（2007）在湖北也发现少量的红 颈瓣蹼㛚。以上研究结果表明, 红颈瓣蹼㗈在江西 周边省份已有分布记录。江西过去未有分布记录可 能因为该物种在江西境内分布数量相对较少。此次

收稿日期：2008-11-17; 接受日期：2008-12-20

基金项目: 江西师范大学博士启动基金; 江西师范大学青年成长基金

“通讯作者（Corresponding author), E-mail: shaomq912@sina.com。男, 江苏盐城人, 博士, 副教授, 主要从事鸟类多样性和濒危动物保护 生物学研究 
在遂川机场附近湿地发现的红颈瓣蹼预为江西鸟 类物种新记录。

\section{参考文献:}

Gao WP, Han YP, Li CM. 2000. Resources and protection of some Non-passerifomes birds in Taifu area[J]. Sichuan Journal of Zoology, 19(4): 241-242. [高维平, 韩曜平, 李春梅. 2000. 太湖流域涉禽资源 及保护. 四川动物, 19(4):241-242.]

Huang SL, Hang LX, Gao SZ, Luo ZY. 2006. Diversity of migratory birds during autumn Nights in Fenghuang Mountains, Nanjian County, Yunnan Province[J]. Zool Res, 27(2): 163-168. [黄石林, 韩联宪, 高 素珍, 罗增阳. 2006. 云南南涧风凰山秋季夜间迁移鸟类多样性分 析. 动物学研究, 27 (2) : 163-168.]

MacKinnon J, Phillipps K, He FQ. 2000. A Field Guide to the Birds of
致谢：感谢审稿专家对本文提出的宝贵意见。

China [M]. Changsha: Hunan Education Press. [约翰·马敬能,卡伦·菲 利普斯, 何芬奇. 2000. 中国鸟类野外手册. 长沙: 湖南教育出版社.] Zheng GM. 2005. A Checklist on the Classification and Distribution of the Birds of China[M]. Beijing: Science Press.[郑光美. 2005. 中国鸟类 分类与分布名录. 北京: 科学出版社.]

Zhong FS, Yan HM, Li LP, Jiang Y, Yao Y, Deng XJ. 2007. Community structure and diversity of birds on East Dongting Lake Wetland of Hunan Province[J]. Chinese Journal of Ecology. 26(12): 1959-1968. [钟福生, 颜亨梅, 李丽平, 蒋 勇, 姚毅, 邓学建. 2007. 东洞庭湖 湿地鸟类群落结构及其多样性. 生态学杂志, 26(12): 1959-1968.] 